\title{
Expression Virus-Like Particles (VLPs) at Geomembrane and Concrete in Asian Pacific Shrimp Culture (Litopenaeus vannamei)
}

\author{
Venny Nur Hidayah ${ }^{1}$, Muhammad Musa², Yuni Kilawati² \\ ${ }^{1}$ Master Program of Aquaculture, Faculty of Fisheries and Marine Science, University of Brawijaya, Malang, Indonesia \\ ${ }^{2}$ Departement of Aquatic Resources Management, Faculty of Fisheries and Marine Science, University of Brawijaya, \\ Malang, Indonesia
}

\section{Abstract}

Asian Pacific Shrimp is an invertebrate that the most culture in aquaculture. But the high demand for shrimp makes farmers cultivate a high density. There are several ways to increase the density of shrimp culture, usually called geomembrane plastic and concrete ponds. The ponds are located in the Laboratory of Brackishwater and Seawater Fisheries, Probolinggo and Lucky Windu, Situbondo. Day of Culture (DOC) on Laboratory of Brackishwater and Seawater Fisheries in Probolinggo pond is 85 days both, while in Lucky Windu Situbondo is 81 days on pond 2, and pond 3B 133 days. The study aimed to evaluate correlations of VLPs towards geomembrane and concrete ponds. The research method has two observations: 1 . Periodic observations; nitrite, ammonium, and shrimp were observed; 2 . Last observation; sampling water for analysis VLPs was observed. Data of sampling water in the different ponds were then analyzed using Pearson correlation analysis to look for the level of tightness and direction of the relationship. The results have obtained that geomembrane VLPs and concrete VLPs has a very strong relationship, while the type of geomembrane and concrete was close to $1>0.5$ and the result is $0.90,0.96,0.69$, and 0.82 . Water quality showed pH 8.1 at geomembrane, nitrite $0.2 \mathrm{mg} \cdot \mathrm{L}^{-1}$ at geomembrane, and ammonium of $0.44 \mathrm{mg} \cdot \mathrm{L}^{-1}$ at concrete. The pond area in geomembrane pond 1 and 2 was $1600 \mathrm{~m}^{2}$, meanwhile in concrete both is $4300 \mathrm{~m}^{2}$, which mean in concrete ponds more the existence of VLPs is because due to the different pond area factors and indicates from detections of WSSV that the result was positive that makes environment factor in abundances VLPs. But VLPs have no effect on the growth of shrimp vaname during the cultivated process.

Keywords: Asian Shrimp Pasific (L. vannamei), Virus-Like Particles (VLPs), Water Quality, and WSSV.

\section{INTRODUCTION}

Asian shrimp pacific (Litopenaeus vannamei) is widely cultivated in Indonesia as an alternative to the cultivation of shrimp tiger ( $P$. monodon) [1]. The high demand for vannamei shrimp increased annually in 2015 by 615,871 tons, in 2016 amounted to 698,138 tons, in 2017 amounted to 920,051 tons, in 2018 amounted to 931,338 tons and in 2019 amounted to 1,053,205 tons [2].

With the high demand for shrimp among the community, farmer's cultivation increases density, one of which is the use of geomembrane ponds and concrete. Geomembrane plastic has the function to coat or cover the entire pool to the bottom (ground level). Concrete ponds themselves can prevent water leakage as well as improve uneven or stable soil texture [3]. In addition to density, monitoring water quality is also important to maintain the stability of aqua culture ecosystems. When the lack of water quality control and weather changes are significant, it can cause shrimp to experience

\footnotetext{
${ }^{*}$ Correspondence Address:

Venny Nur Hidayah

Email : vennynhidayah@gmail.com

Address : Faculty of Fisheries and Marine Science, University of Brawijaya, Veteran Malang, 65145
}

stress. Stress factors affect the immune response in shrimps that are then susceptible [4]. Because water is an important requirement because it can affect the survival of fish, the development, growth, and level of shrimp production [5].

If the water quality decreases, it will be easier for harmful pathogenic organisms to multiply rapidly. The spread of pathogenic organisms can be vertically and horizontally. Vertically, from the base of the pond sediment to the surface of the pond [6] and horizontally from a particle can transfer the intergenic genes that enter into other particles. The particles can be called VLPS (Virus-Like Particles).

Virus-like particles (VLPs) are particles derived from protein capsids that belong to viruses but do not contain biological DNA structures [7]. VLPs contain bacterial and viral genes, where VLPS exist, the host must have the potential infecting bacteria and viruses [8]. The content of VLPs in the aquatic environment of shrimp farms will directly affect the accumulation of VLPS in the shrimp body through the respiratory.

The presence of VLPS can cause primary and secondary infections by bacteria, which commonly occur on a large scale due to virusinfected organisms, resulting in decreased production in aquaculture and leading to large 
economic losses. Precise observation of the abundance of VLPS particles is very important as ecological monitoring in a business of shrimp farming [9]. Based on previous research, the VLPS expression of the sample can be observed using a Confocal Laser Scanning Microscope (CLSM).

The relationship of VLPs with sample water depends on temperature, $\mathrm{pH}$, complexions, encapsidated molecules. VLPs are formed through the nucleation process, aided by electro static interactions between dimer capsid proteins and the genome of viruses. Further interaction is carried out by capsid proteins. Capsid proteins then form a wall of capsid protein structure. In dimers, capsid proteins stick together to form complex proteins and show the condition of intact protein capsids [10]. From the description above, it is necessary to conduct research related to the correlation of VLPS geomembrane and concrete.

\section{MATERIAL AND METHOD \\ Water Sampling}

The research was in February-May 2021. Water collected in two locations: Laboratory of Brackishwater and Seawater Probolinggo, East Java and Lucky Windu Situbondo, East Java. Water samples took to Laboratory in Probolinggo, using two ponds of geomembrane, and the spot taking the sample in the inlet and outlet. The detail spot for taking water sampling at the surface with depths of $40 \mathrm{~cm}$ and above sediment (pool bottom) is $4 \mathrm{~cm}$ [11]. It is also applied at Lucky Windu concrete ponds. The reason why used two types of ponds (geomembrane and concrete) is geomembrane plastic has the function to coat or cover the entire pool to the bottom (ground level). Concrete ponds themselves can prevent water leakage as well as improve uneven or stable soil texture [3]. The water sample was given PFA (paraformaldehyde) $4 \%$ tightly closed and coated with aluminum foil and stored in a coolbox with a temperature of $7^{\circ} \mathrm{C}$ and in closed conditions.

\section{VLPs water sample Analysis Procedure}

The water sample obtained was then taken 5 $\mathrm{mL}$ (3.5 mL of water sample and 1.5 PFA 4\%). Samples were processed between 24 hours and 96 hours [12]. Water samples taken $1 \mathrm{~mL}$ were dripped over a simple vacuum (membrane 0.025 $\mu \mathrm{L}$ and filter $0.2 \mu \mathrm{m}$ in syringe) little by little. Then it is pumped slowly until the water is filtered and enters the syringe. The membrane (Anodisc or Whatman) with pore $0.025 \mu \mathrm{L}$ wait until wind-cooled. Bacteria and viruses were stained by slightly modifying the protocol [13] after collecting viruses and bacteria on an Anodisc or Whatman filter with a pore size of $0.025 \mu \mathrm{L}$. Create a staining solution by adding (97.6 $\mu \mathrm{L}$ deionized Water Sterile $+2.5 \mu \mathrm{L}$ SYBR DNA Gel Stair) to Eppendorf Tubes $2 \mathrm{~mL}$ in dark conditions. Using SYBR Gold dissolved 10,000 times in dimethyl sulfoxide, at a final concentration of 3.3 times this stain, higher fluorescence yield compared to SYBR Green I or II. The staining solution is homogenized. Given a staining solution of $100 \mu \mathrm{L}$, then drip on a petridish. The $0.025 \mu \mathrm{L}$ membrane is placed on top of the staining solution and incubated for 18 minutes. The membrane of $0.025 \mu \mathrm{L}$ is windcooled. Given one drop of fluorescent mounting on the glass cover. The membrane is placed on the glass cover and closed [12]. Observations were made using CLSM (Confocal Laser Scanning Microscope). For further calculations, digital images were created using a DMIRE 2 confocal scanning laser microscope with a TCS SP2 confocal system (Leica Microsystems, Germany).

\section{Sampling Shrimp Organ and DNA Isolations}

The DNA isolation from shrimp is $6 \mathrm{~cm}$ and took gills by opening the carapace of the head, swimming legs (pleopods), or tail. After that, pooling or merging and then put in microtube 1.5 $\mathrm{mL}$ and labeled each microtube. Furthermore, shrimp samples were counted and weighed as much as $0.05 \mathrm{~g}$ for DNA extraction. The next stage is DNA quantifiable testing, amplification, and electrophoresis [14]. Pleopods and tails are one of the target organs that are easily infected with WSSV. In addition, WSSV (which is still infectious in soil sediments) allows transmission of WSSV through mobile devices (including pleopods). Meanwhile, gill was in direct contact with the environment $[14,15]$.

\section{Detection WSSV Virus with RT-PCR}

PCR test conducted using primary ICP11 (Wsv230_19F22:5'GACGCCGATTTCTTGCTGGTGG 3'danWsv230_202R24:5'GGGTTGAATCTCCAGCG TTGAATC3') with PCR program: Hotstart: $95^{\circ} \mathrm{C}$ for 3 minutes, Denaturation: $94^{\circ} \mathrm{C}$ for 1 minute, Annealing: $59^{\circ} \mathrm{C}$ for 1 minute, extension: $72^{\circ} \mathrm{C}$ for 1 minute (35 cycles), Postextention: $72^{\circ} \mathrm{C}$ for 7 minutes. Then visualized using geldoc [15].

\section{VLPs at Convocal Laser Scanning Microscopy (CLSM)}

The membrane pore $0.025 \mu \mathrm{L}$ is placed on the microscope preparation table and then 
observed with a magnification of 400x. The acquired image is then marked, then the image that has been calculated the number of VLPs is stored in a folder that has been named. The images to be analyze dare adapted to the data in Microsoft Excel to make it easier to group the data [12].

\section{pH}

$\mathrm{pH}$ measurements are carried out periodically for three weeks and obtained the average $\mathrm{pH}$ per week. The procedure for using a $\mathrm{pH}$ meter based on SNI (2004) is as follows: The $\mathrm{pH}$ meter is calibrated with a buffer solution according to the tool's working instructions each time. It will take measurements. Rinse the electrodes with mineral-free water, then dry them with soft tissue. Dipping electrodes into test samples up to $\mathrm{pH}$ meters shows a steady reading. Record the scale or number readings on the display from the $\mathrm{pH}$ meter. Record the temperature at the time of $\mathrm{pH}$ measurement and report the result. Rinse the electrodes again with mineral-free water after measurement [16].

\section{Nitrite}

Nitrite measurements are carried out periodically for three weeks and obtained the average Nitrite per week. Nitrite measurement procedure was using Nitrite Testkit Hanna Instrument $\mathrm{HI}$ : 3873. The following nitrite measurement fills the cuvet glass with $10 \mathrm{~mL}$ of the sample until the mark is stated. We added one package of hi 3873-0 Nitrite Reagent. The lid was reattached, and the sample was shaken for 1 minute, and we wait for 1 minute to allow the color to develop. The lid was removed, and the color comparison cube was filled with $5 \mathrm{~mL}$ of a treated water sample. We determined which color matches the solution in the cube and record the result in $\mathrm{mg} . \mathrm{L}^{-1}$ (or ppm) nitrite. It is better to match the color 20 with a white cloth to make it visible about $10 \mathrm{~cm}$ behind the comparison. The reading to $\mathrm{mg} \cdot \mathrm{L}^{-1}$ nitrite was converted, then multiply the reading by a factor of $4.43[17,18]$.

\section{Ammonium}

Ammonium measurements are carried out periodically for three weeks and obtained the average ammonium per week. The measurement of ammonium content can be done using the Nessler method in spectrophotometry with a wave length of $425 \mathrm{~nm}$. How to measure ammonium content in the sample is: water samples are filtered using Whatman No. 42 filter paper, filtered sample water is then picked up as much as $10 \mathrm{~mL}$ and inserted into the reactor tube. Nessler reagents of four drops were added and homogenized using a vortex mixer for 30 seconds, and waited for 10 minutes. Measured using a spectrophotometer at a wavelength of $425 \mathrm{~nm}$. Ammonium levels in the sample are calculated by the formula = Sample Absorbance/ Slope [17].

\section{Growth Asian Pacific Shrimp Analyze}

Shrimp sampling was needed to calculate the initial weight at stocking and final weight at the beginning of stocking until harvest time. The initial weight and final weight are measured [19].

\section{Data Analysis}

Pearson correlation analys is is used to look for the level of tightness and direction of the relationship of VLPS in geomembrane and concrete pond. The higher correlation value, the higher the tightness of the relationship between the two variables. Minus (-) and plus (+) signs on correlation values represent the nature of the relationship. Correlation values are 0.00 to 0.5 medium correlations and if $>0.5$ correlations are very strong [20]. If the corrective value is minus, the relationship between the two tables is unidirectional. If the correlation value is marked plus, the relationship between the two tables is in the opposite direction [21]. The formula for Pearson correlation analysis is as follows [22]:

$$
\mathrm{r}_{p m}=\frac{\mathrm{n}\left(\sum \mathrm{xy}\right)-\left(\sum \mathrm{x}\right)\left(\sum \mathrm{y}\right)}{\sqrt{\left\{\mathrm{n}\left(\left(\sum \mathrm{x} 2\right)-\left(\sum \mathrm{x}\right) 2\right)\right\}\left\{\left(\mathrm{n} \sum \mathrm{y} 2-\left(\sum \mathrm{y}(2)\right\}\right.\right.}}
$$

\section{RESULTS AND DISCUSSION}

\section{Detection of Vaname Shrimp infected with WSSV in RT-PCR}

Shrimp samples obtained after the PCR test were positive. In this case, the virus replicates repeatedly in other target organs.

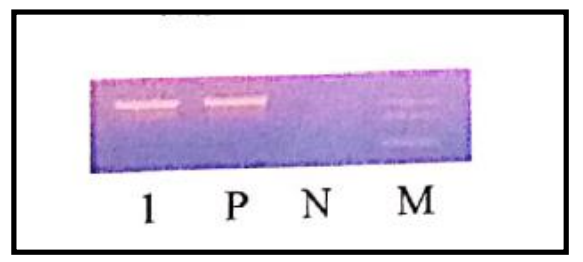

Figure 1. WSSV PCR results are positive; numbers $1=$ sample wells; $M=D N A$ marker indicator (100$1000 \mathrm{bp}) ; \mathrm{N}=$ negative control and $\mathrm{P}=$ positive control.

The transmission of WSSV consists vertically or horizontally [23]. Vertically, it is transmitted generatively through the infected broodstock to 
heredity, while horizontally can go through the food chain, so that virion in the environment enters the body of the shrimp. In addition, it can also occur due to transmission factors and reservoir infections [24].

The result from PCR was positive (Fig. 1) because virus infection is a vector in the spread of shrimp disease presence of VLPs [25] and the abundance of bacteria with correlation with viruses [26]. Pathogens or foreign bodies that enter the body can VLPs, viruses, or bacteria that are harmfullf the VLPs are high, then the virus bacteria ratio (VBR) can easily infect the host. Although largely unproven, viral infections remain the main possible vector for the spread of shrimp disease [27].

\section{Analysis of Water Quality}

pH

$\mathrm{pH}$ is the degree of acidity used to express the level of acidity or wetness possessed by water [28]. $\mathrm{pH}$ in the range of 7.5-8.5 [29].

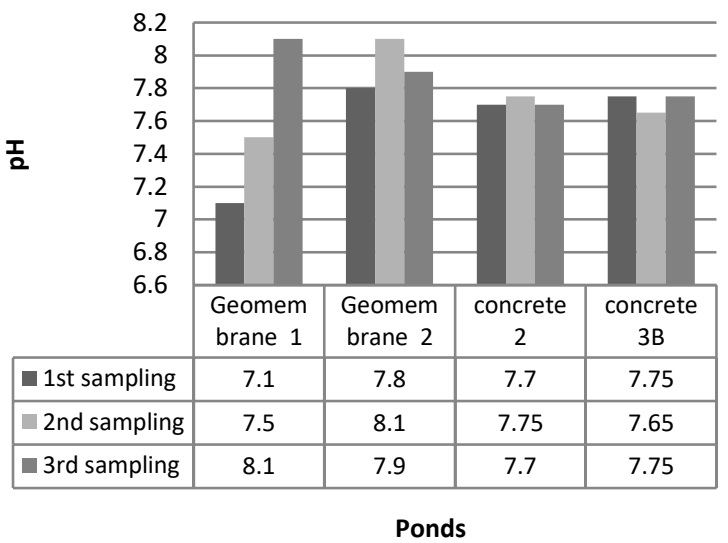

Figure2. $\mathrm{pH}$ measurements performed on sampling in Geomembrane and Concrete.

The highest $\mathrm{pH}$ in the $1^{\text {st }}$ sampling was geomembrane 2 for 7.8 , while for the $2^{\text {nd }}$ sampling was found in geomembrane 2 by 8.1 . In the $3^{\text {rd }}$ sampling, the highest $\mathrm{pH}$ was measured in geomembrane 1 for 8.1. Meanwhile, the lowest $\mathrm{pH}$ in $1^{\text {st }}$ sampling was geomembrane 1 for $7.1,2^{\text {nd }}$ sampling was concrete $3 \mathrm{~B}$ for 7.65 , and $3^{\text {rd }}$ sampling was concrete 2 for 7.7 (Fig. 2).

The average $\mathrm{pH}$ in a shrimp pond is 6.2-10.2 [30]. Reducing carbon dioxide during the day is helped by the process of photosynthesis, and at night, carbon dioxide increases because it is produced from shrimp. If there is heavy rain and acidic soil, then the $\mathrm{pH}$ can reach 4.1 [31]. The stability of structure VLPs under different $\mathrm{pH}$ and ions does not play a major role in the abundance of VLPs [32].

Factors that caused an abundance of VLPs are nutrient availability and the primary productivity of coral ecosystems concerning other microorganisms (prokaryotes) that was determined [33]. According to the new experiment about VLPs, the relationship between the abundance of VLPS and hydrographic factors, nutrient availability, as well as primary productivity in the coral ecosystem was clarified [9]. Parameters that significantly had negative relations are dissolved oxygen, temperature, $\mathrm{pH}$, salinity, and total phytoplankton [9]. The stability of the structure of VLPs under different $\mathrm{pH}$ and ions does not play a major role in the abundance of VLPs [32].

\section{Nitrite}

Nitrite is an unstable gas affected by dissolved oxygen and is a transition from ammonium and nitrates to the nitrification process [34]. The highest nitrite in $1^{\text {st }}$ sampling was measured in geomembrane 1 for $0.2 \mathrm{ppm}$, while in the $2^{\text {nd }}$ sampling was measured in geomembrane 2 for $0.2 \mathrm{ppm}$, and in $3^{\text {rd }}$ sampling was measured in geomembrane 1 for $0.1 \mathrm{ppm}$. The lowest nitrite in the $1^{\text {st }}$ sampling was found in concrete $3 \mathrm{~B}$ for $0.02 \mathrm{ppm}$, in the $2^{\text {nd }}$ sampling was found in concrete 2 for $0.03 \mathrm{ppm}$, and for the $3^{\text {rd }}$ sampling was in concrete $3 \mathrm{~B}$ for $0.03 \mathrm{ppm}$ (Fig. 3).

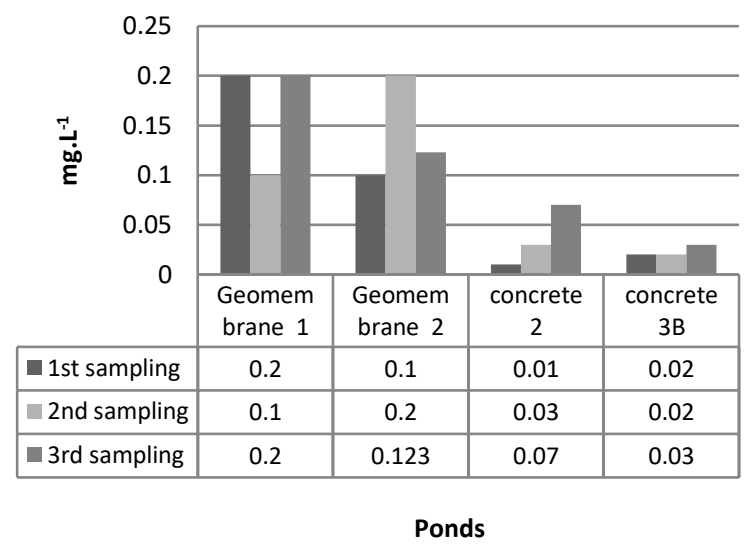

Figure3. Nitrite measurements performed on sampling in Geomembrane and Concrete.

In the previous study, nitrite and nitrate concentrations in the treatment ponds were lower during most of the experimental period [35]. During the nitrification process, hydrogen ions are produced and released in to the water column [36], which is likely to cause the 
reduction of $\mathrm{pH}$ in there environment. In this study also, a similar trend was observed. The $\mathrm{pH}$ in the treatment ponds decreased with an increase in rearing time. The increase in turbidity of the water column could be the result of the increase in levels of suspended particles [37] and the addition of large amounts of artificial feed in the rearing environment [38]. Nitrite levels based on SNI01-7246 200 are $<0.01 \mathrm{mg} . \mathrm{L}^{1}$ [39]. Factors that cause the abundance of VLPs are because the organic matter in the water enters the host, including algae, and in the water wastewater [40].

During the process of ammonia oxidation to nitrite, alkalinity in form of carbonated or bicarbonates is consumed, which causes the system $\mathrm{pH}$ to go down and the ammonia oxidation to slow down. Evidence that low $\mathrm{pH}$ induces prophage in ammonia oxidizers is novel [41]. A positive significant correlation was found between VLPS, bacteria, and VBR and nutrients (nitrate, ammonium, DIN) [9].

\section{Ammonium}

Ammonium and nitrate compounds are an important part of the watered nitrogen cycle. Denitrification is a reaction of reducing nitrates to nitrites, nitrite oxides, and nitrogen gases. Meanwhile, nitrogen fixation is the binding of nitrogen gas to ammonia and organic nitrogen. This process occurs in a trial involving symbiosis between algae and bacteria [42].

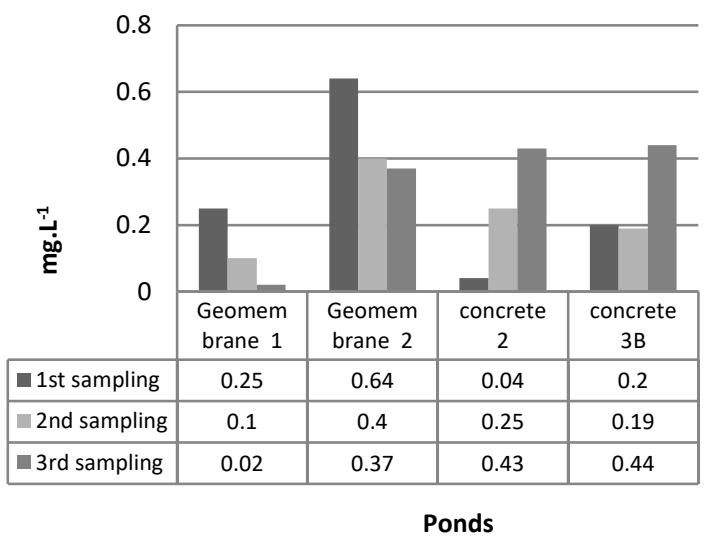

Figure4. Ammonium measurements were pertormed on sampling in Geomembrane and Concrete.

The highest ammonium in the $1^{\text {st }}$ sampling was found in geomembrane 2 for $0.64 \mathrm{ppm}$, in the $2^{\text {nd }}$ sampling was found in geomembrane 2 for $0.4 \mathrm{ppm}$, and in the $3^{\text {rd }}$ sampling, was found in concrete 3B for $0.44 \mathrm{ppm}$. Conversely, the lowest ammonium in the $1^{\text {st }}$ sampling was measured in concrete 2 for $0.04 \mathrm{ppm}, 2^{\text {nd }}$ sampling in concrete
3B for $0.19 \mathrm{ppm}$, and $3^{\text {rd }}$ sampling in geomembrane 1 for $0.02 \mathrm{ppm}$.

Ammonium levels can also increase due to the influence of the $\mathrm{pH}$ of the waters. If the $\mathrm{pH}$ value of an expansion is lower, then the level of ammonium in the water becomes higher [43]. Ammonium concentration in ponds exceeding $0.45 \mathrm{ppm}$ can inhibit shrimp growth by up to $50 \%$. For shrimp to grow well enough, ammonium contained in pond water should not be more than $0.01 \mathrm{ppm}$ [39]. The presence of high amounts of ammonium in the waters affects stress in biota [44].

These viral-mediated lysates will enhance the transfer of nutrients from particulate to dissolved and will be then utilized by uninfected bacteria. As a result, viruses play an important role in the recycling of nutrients and carbon. These viral lysates are rich in free and combined amino acids and therefore, are a potentially important source of labile organic $\mathrm{N}$, which is taken by bacteria and produced ammonium as a by-product.

Furthermore, the bacterial counts indicate that uninfected bacteria might convert the dissolved organic nitrogen into inorganic resulting in a higher concentration of nitrite and ammonium. Then, the latter will be consumed by phytoplankton, thus increasing its biomass, which explains the high abundance and biomass of plankton in located B, particularly the diatoms. Hence, the viral lysates at located Bare triggered mostly by infection of bacterial cells, owing to the high VBR and its low biomass. This state explained the positive significant correlation between VLPS, bacteria, and VBR, and nutrients (nitrate and ammonium). As a result, the viral lysis will stimulate bacterial metabolism characterized as a major $\mathrm{N}$ source that drives primary production in the ocean. In other words, viral activity will indirectly fuel plankton productivity that requires enough amounts of nutrients for its growth [9].

\section{Growth of Asian Pacific Shrimp}

The daily average growth (ADG) of vaname shrimp after the age of over 60 days generally ranges from $0.2 \mathrm{~g}-0.3 \mathrm{~g}$. The growth of Asian Pacific Shrimp was showed in following Table 1. Daily growth obtained in this study after the age of 80 days is $0.10 \mathrm{~g}-1.14 \mathrm{~g}$. The rate of growth of individuals shows a decrease with the increase in average weight as the maintenance period increases [19].

Shrimp growth is influenced by many factors, namely internal and external factors. Internal 
factors include sex, age, size, and maturity level of the gonads, while external factors are divided into two groups, namely biotic and abiotic factors. Biotic factors are feed and stocking density, while the dominant abiotic factors are temperature, oxygen, salinity, light, and toxic materials [45]. That besides being supported by good feed and environment. Shrimp growth is also determined by stocking density. High stocking density of shrimp will result in slow growth due to competition for space and feed. Such condition will affect the growth of the reared shrimp [46]. The growth of white shrimp is influenced by a combination of several factors, namely water quality (including water temperature), seed quality, feed quality, amount of feed, and stocking density [47].

Environment can affect replication virus and the production of VLPS at the rate of cell growth under metabolism, DNA transcription and replication, mRNA translation and protein PTM. The environment in question includes the concentration of dissolved oxygen (DO), $\mathrm{pH}$, temperature, agitation rate, cell and substrate concentration, inlet gas composition flow, volume, pressure, dynamics and fluids [48]. abundance of VLP in each plot significantly correlated with turbidity. there is a correlation between the abundance of VLP and particles suspended in eutrophic water columns and oligotrophic estuaries. Particles suspended in Water is mainly composed of organic matter [49].

Table 1. The growth of Asian Pacific Shrimp

\begin{tabular}{|c|c|c|c|}
\hline Sampling & Ponds & Weight (g) & Size $\left(\Sigma . g^{-1}\right)$ \\
\hline \multirow[t]{8}{*}{$1^{\text {st }}$} & Geomembrane 1 & & \\
\hline & DOC 42 & 3.36 & 297 \\
\hline & Geomembrane 2 & & \\
\hline & DOC 42 & 2.18 & 100 \\
\hline & Concrete 2 & & \\
\hline & DOC 42 & 4.7 & 212 \\
\hline & Concrete 3B & & \\
\hline & DOC 42 & 4.5 & 222 \\
\hline \multirow[t]{8}{*}{$2^{\text {nd }}$} & Geomembrane 1 & & \\
\hline & DOC 54 & 7.9 & 126 \\
\hline & Geomembrane 2 & & \\
\hline & DOC 52 & 2.8 & 35 \\
\hline & Concrete 2 & & \\
\hline & DOC 49 & 6.8 & 147 \\
\hline & Concrete 3B & & \\
\hline & DOC 49 & 6.8 & 147 \\
\hline \multirow[t]{8}{*}{$3^{\text {rd }}$} & Geomembrane 1 & & \\
\hline & DOC - & - & - \\
\hline & Geomembrane 2 & & \\
\hline & DOC - & - & - \\
\hline & Concrete 2 & & \\
\hline & DOC 56 & 8.8 & 133 \\
\hline & Concrete 3B & & \\
\hline & DOC 56 & 8.7 & 114 \\
\hline
\end{tabular}

\section{Analysis Correlation of VLPs in Geomembrane and Concrete}

The data provide that geomembrane and concrete pondshave strong correlations. VLPs in geomembrane 1 has abundance VLPs in CLSM of 22 particles. $\mathrm{m}^{-3}$, and geomembrane 2 has 250 particles. $\mathrm{m}^{-3}$. Meanwhile, concrete 2 has an abundance VLPS in CLSM, which is 314 particles. $\mathrm{m}^{-3}$, and concrete 3B has 139 particles. $\mathrm{m}^{-3}$. The pond area in geomembrane pond 1 and 2 was $1600 \mathrm{~m}^{2}$. Meanwhile in concrete, both are $4300 \mathrm{~m}^{2}$, which means concrete ponds have more VLPs due to the different pond area factors [33]. Besides pond, other factors that caused the abundance VLPS were bacterial cycles and nutrients $[6,9]$.

Compared to the abundance of VLPS in aquaculture waters, VLPs are often found in the sea [50]. Usually, VLPs are found in coral reef areas or the depths of the sea [27]. The concentration of VLPS in the ocean ranges from $1.7 \times 10^{6}$ particles. $\mathrm{m}^{-3}$ to $4.0 \times 10^{7}$ particles. $\mathrm{m}^{-3}$ [8]. The environment can affect viral replication and production of VLPs at the rate of cell growth in a state of metabolism, DNA transcription, and replication, translation of mRNA, and PTM proteins. The environment in question includes dissolved oxygen concentration (DO), $\mathrm{pH}$, temperature, agitation rate, cell and substrate concentration, incoming gas composition flow, volume, pressure, dynamics, and fluids [48].
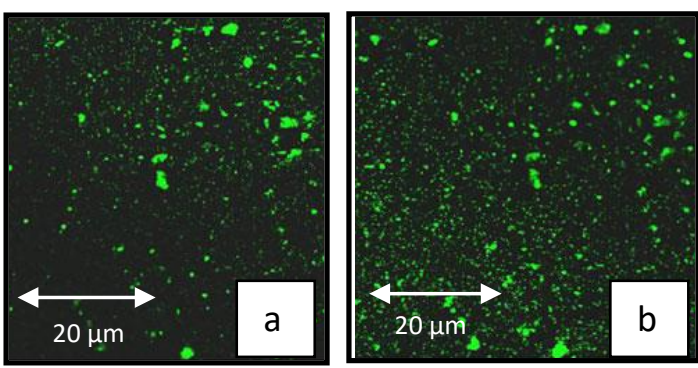

Figure 5. Visualisation VLPS in Confocal Laser Scanning Microscopy (CLSM), abundance VLPS in geomembrane (a) and VLPs in concrete (b)

Table 2. Correlations VLPs in Geomembrane and Concrete

\begin{tabular}{clc}
\hline No & \multicolumn{1}{c}{ Pond } & $\begin{array}{c}\text { Correlation of } \\
\text { VLPs }\end{array}$ \\
\hline 1 & Geomembrane 1 - Concrete 2 & 0.90 \\
2 & Geomembrane 2 - Concrete 3B & 0.96 \\
3 & Geomembrane 1 - Concrete 2 & 0.69 \\
4 & Geomembrane 2 - Concrete 3B & 0.82 \\
\hline
\end{tabular}

There is a correlation between the abundance of VLPs and suspended particles in eutrophic water columns and oligotrophic estuaries. 
Suspended particles in the waters are mainly composed of organic matter [49]. Depth can affect the distribution of virus-like particles (VLP). The range of VLPs abundance in the sample of pelagic organisms attached to the sediment is smaller than the VLPs abundance range in benthic samples [6].

\section{CONCLUSION}

Pearson correlation value showed that VLPS in geomembrane and concretehave a strong relationship, close to 1 . Concrete ponds have more VLPs due to the different pond area factors. Detections of WSSV result was positive that indicates environment factor in abundances VLPs. However, VLPS have no effect on the growth of shrimp vaname during the cultivated process.

\section{ACKNOWLEDGEMENT}

We would like to thank University Leading Applied Research (PTUPT), Institute of Research and Community Service through Non-Tax State Revenue Funds (PNBP) University of Brawijaya, in accordance with the Budget Implementation List (DIPA) for funding this research.

\section{REFERENCES}

[1] Srinivas, D., Ch. Venkatrayulu, B. Swapna. 2016. Sustainability of exotic shrimp Litopenaeus vannamei (Boone, 1931) farming in coastal Andhra Pradesh, India: Problems and Issues. Eur. J. Exp. Biol. 6(3). 80-85.

[2] Ministry of Marine and Fisheries. 2019. Performance Report of Directorat General of Fisheries Aquaculture, Ministry of Marine and Fisheries. Republic of Indonesia. Jakarta.

[3] Novitasari, D., S.M. Prayitno, Sarjito. 2016. Analisa faktor risiko yang mempengaruhi serangan Infectious Myonecrosis Virus (IMNV) pada budidaya udang vanamei (Litopenaeus vannamei) secara intensif di Kabupaten Kendal. Prosiding Seminar Nasional Hasil-Hasil Penelitian Perikanan dan Kelautan ke-VI. Faculty of Fisheries and Marine Science - Research Center for Disaster Mitigation and Coastal Rehabilitation. Diponegoro University. 640649.

[4] Liu, G., S. Zhu, D. Liu, X. Guo, Z. Ye. 2017. Effects of stocking density of the white shrimp Litopenaeus vannamei (Boone) on immunities, antioxidant status, and resistance against Vibrio harveyi in a biofloc system. Fish Shellfish Immunol. 67. 19-26.

[5] Fauzia, S.R., S.H. Suseno. 2020. Resirkulasi air untuk optimalisasi kualias air budidaya ikan nila nirwana (Oreochromis niloticus). Jurnal Pusat Inovasi Masyarakat. 2(5). 887892.

[6] Filippini, M., M. Middleboe. 2007. Viral abundance and genome size distribution $i$ the sediment and water column of marine and freshwater ecosystems. FEMS microbiol Ecol. 60. 397-410.

[7] Jariyapong, P., C. Chotwiwatthanakun, S. Direkbusarakom, I. Hirono, S. Wuthisuthimethavee, W. Weerachatyanukul. 2015. Delivery of double stranded RNA by Macrobrachium rosenbergii nodavirus-like particles to protect shrimp from white spot syndrome virus. Aquaculture. 435. 86-91.

[8] Prussin, A.J., E.B. Garcia, L.C. Marr. 2015. Total concentrations of virus and bacteria in indoor and outdoor air. Environ. Sci. Technol. Lett. 2(4). 84-88.

[9] Ramphul, C., E.C. Beatriz, S.Y. Toshiyuki, Koichi, Y. Thamasak, S. Yoshimi. 2015. Abundance of Virus-like Particles and its links to phytoplankton, bacteria and nutrients cycling in coastal coral ecosystem. Eco-Engineering. 27(3). 81-90.

[10] Strugala, A., J. Jagielski, K. Kamel, G. Nowaczyk, M. Radom, M. Figlerowicz, A. Urbanowicz. 2021. Virus-like particles produces using the brome mosaic virus recombinant capsid protein expressed in bacterial system. Int. J. Mol. Sci. 22(3098): 1-15.

[11] Maia, E.P., G.A. Modesto, L.O. Brito, A.O. Galvez and T.C.V. Gesteira. 2016. Intensive culture system of Litopenaeus vannamei in commercial ponds with zero water exchange and addition of molasses and probiotics. Revista de biología marina y oceanografía. 51(1). 61-67.

[12] Peduzzi, P., M. Agis, B. Luef. 2013. Evaluation of confocal laser scanning microscopy for enumeration of virus-like particles in aquatic systems. Environ. Monit. Assess. 185(7). 5411-5418.

[13] Noble, R.T., J.A. Fuhrman. 1998. Use of SYBR Green I for rapid epifluorescence counts of marine viruses and bacteria. Aquat. Microb. Ecol. 14. 113-118.

[14] Arafani, L., M. Ghazali, M. Ali. 2016. Pelacakan virus bercak putih pada udang vaname (Litopenaeus vannamei) di Lombok 
dengan Real-Time Polymerase Chain Reaction. Jurnal Veteriner. 17(1). 88-95.

[15] Amrillah, A.M., S. Widyarti, Y. Kilawati. 2015. Dampak stres salinitas terhadap prevalensi white spot syndrome virus (wssv) dan survival rate udang vannamei (Litopenaeus vannamei) pada kondisi terkontrol. Res. J. Life Sci. 2(2). 110-123.

[16] SNI. 2004. SNI 06-6989.11-2004. Water and Waste - part $11^{\text {th }}, \mathrm{pH}$ measurement.

[17] Supriatna., M. Mahmudi, M. Musa, Kusriani. 2020. Hubungan $\mathrm{pH}$ dengan parameter kualitas air pada tambak intensif udang vannamei (Litopenaeus vannamei). J. Fish. Mar. Res. 4(3). 368-374.

[18] Hasuti, Y.P. 2011. Nitrifikasi dan denitrifikasi di tambak. Jurnal Akuakultur Indonesia. 10(1). 89-98.

[19] Tahe, Suwardi, H.S. Suwoyo. 2011. Pertumbuhan dan sintasan udang vaname (Litopenaeus vannamei) dengan kombinasi pakan berbeda dalam wadah terkontrol. Jurnal Riset Akuakultur. 6(1). 31.

[20] Pratomo, D.S., E.Z. Astuti. 2015. Analisis regresi dan korelasi antara pengunjung dan pembeli terhadap nominal pembelian di Indomaret Kedungmundu Semarang dengan metode kuadrat terkecil. Jurnal Statistika. 1-12.

[21] Sihombing, Yennita, L. Hutahaean. 2019. Uji komparasi model korelasi dalam menganalisis efektivitas pendampingan petani. Informatika Pertanian. 28(1).1-10. doi: 10.21082/ip.v28n1.2019.p1-10.

[22] Ariani, S., A. Al-Idrus, L. Japa, D. Santoso. 2020. Struktur komunitas makroalga sebagai indikator ekologi ekosistem perairan pada kawasan konservasi laut daerah di Gili Sulat Lombok Timur. Jurnal Biologi Tropis. 20(1). 132-138.

[23] Rahma, H.N., S.B. Prayitnon, A.H.C. Haditomo. 2014. Infeksi white spot syndrom virus (WSSV) pada udang windu (Penaeus monodon Fabr.) yang dipelihara pada salinitas media yang berbeda. J. Aquac. Manage. Technol. 3(3). 25-33.

[24] Rukish, R., G.I. Satriani, R. Rasyid. 2019. Monitoring penyakit WSSV pada budidaya udang windu (Penaeus monodon) di Tambak Tradisional Kota Tarakan. Jurnal Harpodon Borneo. 12(2). 89-95.

[25] Ferreira, N.C., C. Bonetti, W.Q. Seiffert. 2011. Hydrological and Water Quality Indices as management tools in marine shrimp culture. Aquaculture. 318(4). 425433.

[26] Davy, J.E., N.L. Patten. 2007. Morphological diversity of virus-like particles within the surface microlayer of scleractinian corals. Aquat. Microb. Ecol. 47(1). 37-44.

[27] Seymour, J.R., N. Patten, D.G. Bourne, J.G. Mitchell. 2005. Spatial dynamics of viruslike particles and heterotrophic bacteria within a shallow coral reef system. Mar. Ecol. Prog. Ser. 288. 1-8.

[28] Zulius, A. 2017. Rancang BANGUN MONITORING $\mathrm{pH}$ air menggunakan soil moisture sensor di SMK N 1 Tebing Tinggi Kabupaten Empat Lawang. JUSIKOM. 2(1). 37-43.

[29] Arsad, S., A. Afandy, A.P. Purwadhi, B. Maya, D.K. Saputra, N.R. Buwono. 2017. Studi kegiatan budidaya pembesaran udang vaname (Litopenaeus vannamei) dengan penerapan sistem pemeliharaan berbeda. Jurnal Ilmiah Perikanan dan Kelautan. 9(1). 1-14.

[30] George, A., G. A. And N. James. 2018. Effect of pond type on physicochemical parameters, phytoplankton diversity and primary production in, Kisii, Kenya. Int. J. Fish. Aqua. Stud. 6(6). 125-130.

[31] Kathyayani, S. A., M. Poornima, S. Sukumaran, A. Nagavel and M. Muralidhar. 2019. Effect of ammonia stress on immune variables of Pacific white shrimp Penaeus vannamei under varying levels of $\mathrm{pH}$ and susceptibility to white spot syndrome virus. Ecol. Environ. Saf. 184. 1-13.

[32] Samandoulgou, I., R. Hammami, R. M. Rayas, I. Fliss and J. Jean. 2015. Stability of Secondary and Tertiary Structures of VirusLike Particles Representing Noroviruses: Effects of $\mathrm{pH}$, Ionic Strength, and Temperature and Implications for Adhesion to Surfaces. Journal ASM.org. 81. 76807686

[33] Roundnew, B., J.R. Seymour, T.C. Jeffries, T.J. Lavery, R.J. Smith, J.G. Mitchell. 2012. Bacterial and Virus-Like Particle abundances in purged and unpurged groundwater depth profiles. Groundwater Monit. Remediat. 32(4). 72-77.

[34] Makmur, M., H. Kusnoputranto, S. S. Moersidik, D. S. Wisnubroto. 2012. Pengaruh Limbah Organik Dan Rasio N/P Terhadap Kelimpahan Fitoplankton Di Kawasan Budidaya Kerang Hijau Cilincing. 
Jurnal Teknologi Pengelolaan Limbah (J. Waste Manage. Technol). 15(2). 51-64.

[35] Raja, A.R., N. Kalaimani, A. Panigrahi, A.G. Ponniah. 2014. Effect of season and treatment of seed with antibiotics on growout culture of Penaeus monodon (Fabricius, 1798) at Sunderban. India. Turk. J. Fish. Aquat. Sci. 14. 879-885.

[36] Henriksen, K. and W. M. Kemp. 1988. Nitrification in estuarine and coastal marine sediments. In: Blackburn, T.H., J. Sorensen. (Eds). Nitrogen cycling in coastal marine environments. Wiley, New York, USA. 207249.

[37] Wasielesky, W., H. Atwood, A. Stokes, C.L. Browdy. 2006. Effect of natural production in a zero exchange suspended microbial floc based super intensive culture system for white shrimp Litopenaeus vannamei. Aquaculture. 258. 396-403.

[38] Chithambaran, S., M. Harbi, M. Broom, K. Khobrani, O. Ahmad, H. Fattani, A. Sofyani And N. Ayaril. 2017. Green water technology for the production of Pacific white shrimp Penaeus vannamei (Boone, 1931). Indian J. Fish. 64(3). 43-49.

[39] Kilawati, Y. dan Y. Maimunah. 2015. Kualitas Lingkungan Tambak Insentif Litapenaeus vannamei Dalam Kaitannya Dengan Prevalensi Penyakit White Spot Syndrome Virus. Res. J. Life Sci. 2(1). 50-59.

[40] Hisee, A.R., M. Hisee, J. C. McKerral, S. R. Rosenbauer, J. S. Paterson, J. G. Mitchell and H. J. Fallowfield. 2020. Changes of viral and prokaryote abundances in a high rate algal pond using flow cytometry detection. Water Sci. Technol. 82(6). 1-8.

[41] Choi, J., S. M. Kotay and R. Goel. 2010. Various physico-chemical stress factors cause prophage induction in Nitrosospira multiformis 25196- an ammonia oxidizing bacteria. Water Res. 44. 4450-4558.

[42] Carneiro, M.A. Amaral, J.F.J. Resende, S.R. Oliveira, F.O. Fernandes, H.D.S. Borburema, M.S. Barbosa-Silva, A.B.G. Ferreira, E. Marinho-Soriano. 2020. Performance of the agarophyte Gracilariopsis tenuifrons in a multi-trophic aquaculture system with Litopenaeus vannamei using water recirculation. J. Appl. Phycol. 1-10.

[43] Irawan, D. Dan L. Handayani. 2021. tudi kesesuaian kualitas perairan tambak ikan bandeng (Chanos chanos) di Kawasan
Ekowisata Mangrove Sungai Tatah. Budidaya Perairan. 9(1). 10-18

[44] Xue, S., J. Wei, J. Li, X. Geng and J. Sun. 2015. Effects of total ammonia, temperature and salinity on the mortality and viral replication of WSSV-infected Chinese shrimp (Fenneropenaeus chinensis). Aquac. Res. 48(1). 236-245.

[45] Effendie, M.I. 1979. Fishery biological methods. Yayasan Dewi Sri. Bogor.

[46] Mujiman, A., S.R. Suyanto. 1993. Tiger shrimp cultivation. Penebar Swadaya. Jakarta.

[47] Wijayanto, D., D.B. Nursanto, F. Kurohman, R.A. Nugroho. 2017. Profit maximization of whiteleg shrimp (Litopenaeus vannamei) intensive culture in Situbondo Regency, Indonesia. AACL Bioflux. 10. 1436-1444.

[48] Roldao, A., A.C., Sliva, M.C.M. Mellado. 2017. Viruses and Virus-Like Particles in biotechnology: fundamentals and applications. Modul of New University of Lisbon, Institute of Experimental Biology and Technology, Oeiras, Portugal. doi: 10.1016/B978-0-12-809633-8.09046-4.

[49] Nakayama, N., Mami. O. Katsuhiro. I. Susumu. A and Makoto. K. 2007. Seasonal variations in the abundance of viruslike particles and bacteria in the floodwater of a Japanese paddy field. Soil Sci. Plant Nutr. 53(4). 420-429.

[50] Wu, S., L. Zou, H. Wang, J. Xiao, S. Yan, Y. Wang. 2020. Diverse and unique viruses discovered in the surface water of the East China Sea. BMC Genomic. 21(441). 1-15. 